\title{
SPATIAL DISTRIBUTION OF LEAD, ZINC AND CHROMIUM IN THE BOTTOM DEPOSITS OF LAKE SUNIA
}

\author{
ROZKŁAD PRZESTRZENNY OŁOWIU, CYNKU I CHROMU \\ W OSADACH DENNYCH JEZIORA SUNIA
}

\begin{abstract}
Various elements are accumulated in bottom deposits in concentrations that significantly exceed the levels observed in lake water. Under certain conditions, this can lead to secondary contamination of water, posing a threat to aquatic organisms. The aim of this study was to evaluate the spatial distribution of $\mathrm{Pb}, \mathrm{Zn}$ and $\mathrm{Cr}$ pollutants in the bottom deposits of Lake Sunia. The investigated water body is situated in the Olsztyn Lakeland (western part of the Masurian Lakeland), approximately $30 \mathrm{~km}$ north of the city of Olsztyn, in the municipality of Swiatki. The lake has a total area of 111.6 ha and a maximum depth of $8.8 \mathrm{~m}$. The inflow to and the outflow from lake are situated in its south-western and north-western part, respectively. The lake features a bay which is separated from the main water body by a shallow zone. Its catchment area comprises mainly agricultural land. The total area of supply of lake is 450 ha of which inflow catchment area is 70 ha. Most of the catchment area is agricultural land (91\%), and in particular arable land, the rest of the area (5\%) are the barren, and trees (4\%). In the area of the lake is dominated by power-sandy loam soil in the passing sands and clay loam strong little sandy. In terms of particle size are a summary of the soil that is difficult permeable to water and nutrients. Taking into account the valuation of soil classification in the vast quantities of soil are included in the class IVa, IIIIa and IIIb. The average content of organic matter in the lake was determined at $24 \%$. Significant accumulation of organic matter results from intense inflow of biogenic substances from farmed areas in the catchment. The average concentrations of trace elements in the analyzed water body were arranged in the following series: $\mathrm{Cr}<\mathrm{Pb}<\mathrm{Zn}$, and their ratios were determined at $8.1<22.9<45.2$. Higher levels of heavy metals were observed in the profundal zone, whereas lower concentrations of the analyzed elements were noted in littoral zone sediments.
\end{abstract}

Keywords: anthropogenic pressure, bottom deposits, heavy metals

All water reservoirs have their bottom, which settle on the organic and inorganic suspensions. They form a bottom deposits characteristic for catchment and morphological feature [1]. The settlement of allochthonous material formed outside the sedimentation zone and autochthonous material created at the place of sedimentation leads to the formation of bottom sediments in water bodies [2]. The content of chemical compounds in sediments is determined by the type of bed rock forming lake catchments as well as land use patterns in the catchment area. Rock strata constitute a point of reference (geochemical background)

\footnotetext{
${ }^{1}$ Department of Water Resources, Climatology and Environmental Management, University of Warmia and Mazury in Olsztyn, pl. Łódzki 2, 10-756 Olsztyn, Poland, phone +48 895234351

*Corresponding autor: angela.potasznik@uwm.edu.pl
} 
for evaluating the actual enrichment of surface deposits [3]. In the bottom deposits decomposition processes still proceed. The direction and pace of these changes is characteristic of the ecosystem in which there is diverse and specialized organic material groups of organisms both [4]. Human Anthropogenic pressure, particularly industrial lead to increased concentrations of heavy metals in the environment. The source of contamination is an industry, transport and agriculture. Among the heavy metals as an indicator of anthropogenic pressure is mentioned zinc, cadmium, copper and lead [4].

Heavy metals accumulated in bottom deposits are supplied to surface waters with industrial and municipal effluents, discharge from farm fields and grasslands containing fertilizers and pesticides as well as atmospheric dust [5]. The chemical composition of sediments is a good indicator of the quality of the aquatic environment, and it is a richer source of information than the more varied chemical composition of water. The concentration of pollutants in the sediments is the result of two opposing processes of deposition and restarting. Heavy metals, both natural and anthropogenic source get to the surface water primarily with slurry material. Heavy metals are accumulated of bottom deposits by precipitation and sorption effects, because to the organic solubility [6]. Heavy metal analyses supply valuable data for describing the sources, flow rate and distribution of metals in a water body, and analysis results are used to predict the possibility of secondary contamination of water [4]. Bottom sediments are a product of not only processes in the aquatic environment, but also in the whole catchment. In the field of paleolimnology was treated as a kind of archive logging and reliable storage of information on a variety of processes occurring in the reservoir [7].

The aim of this study was to evaluate the spatial distribution of $\mathrm{Pb}, \mathrm{Zn}$ and $\mathrm{Cr}$ pollutants in the bottom deposits of Lake Sunia.

\section{Materials and methods}

The variations in $\mathrm{Pb}, \mathrm{Zn}$ and $\mathrm{Cr}$ concentrations were studied in Lake Sunia situated in the Olsztyn Lakeland in the western part of the Masurian Lakeland. The Olsztyn Lakeland has a predominance of ribbon and barrier lakes surrounded by terminal moraine formations [8]. The presence of numerous lakes significantly contributes to air humidity (82\% on average) and precipitation volume (up to $600 \mathrm{~mm}$ ) [8]. Lake Sunia is situated approximately $30 \mathrm{~km}$ north of the city of Olsztyn in the municipality of Swiatki. It has a total area of 111.6 ha, a maximum depth of $8.8 \mathrm{~m}$ and a capacity of $4,464,000 \mathrm{~m}^{3}$. The inflow to and the outflow from the lake are situated in its south-western and north-western part, respectively.

The total area of supply of lake is 450 ha of which inflow catchment area is 70 ha. Most of the catchment area is agricultural land (91\%), and in particular arable land, the rest of the area $(5 \%)$ are the barren, and trees $(4 \%)$. The lake's catchment area is farmed intensively with a rotation of wheat and rapeseed crops. In the area of the lake is dominated by power-sandy loam soil in the passing sands and clay loam strong little sandy. In terms of particle size are a summary of the soil that is difficult permeable to water and nutrients. Taking into account the valuation of soil classification in the vast quantities of soil are included in the class IVa, IIIa and IIIb. Lake Sunia comprises the main water body and a bay separated by a shallow zone (Fig. 1). The lake has a diverse shoreline which is nearly entirely overgrown with emergent vegetation. 
a)

b)

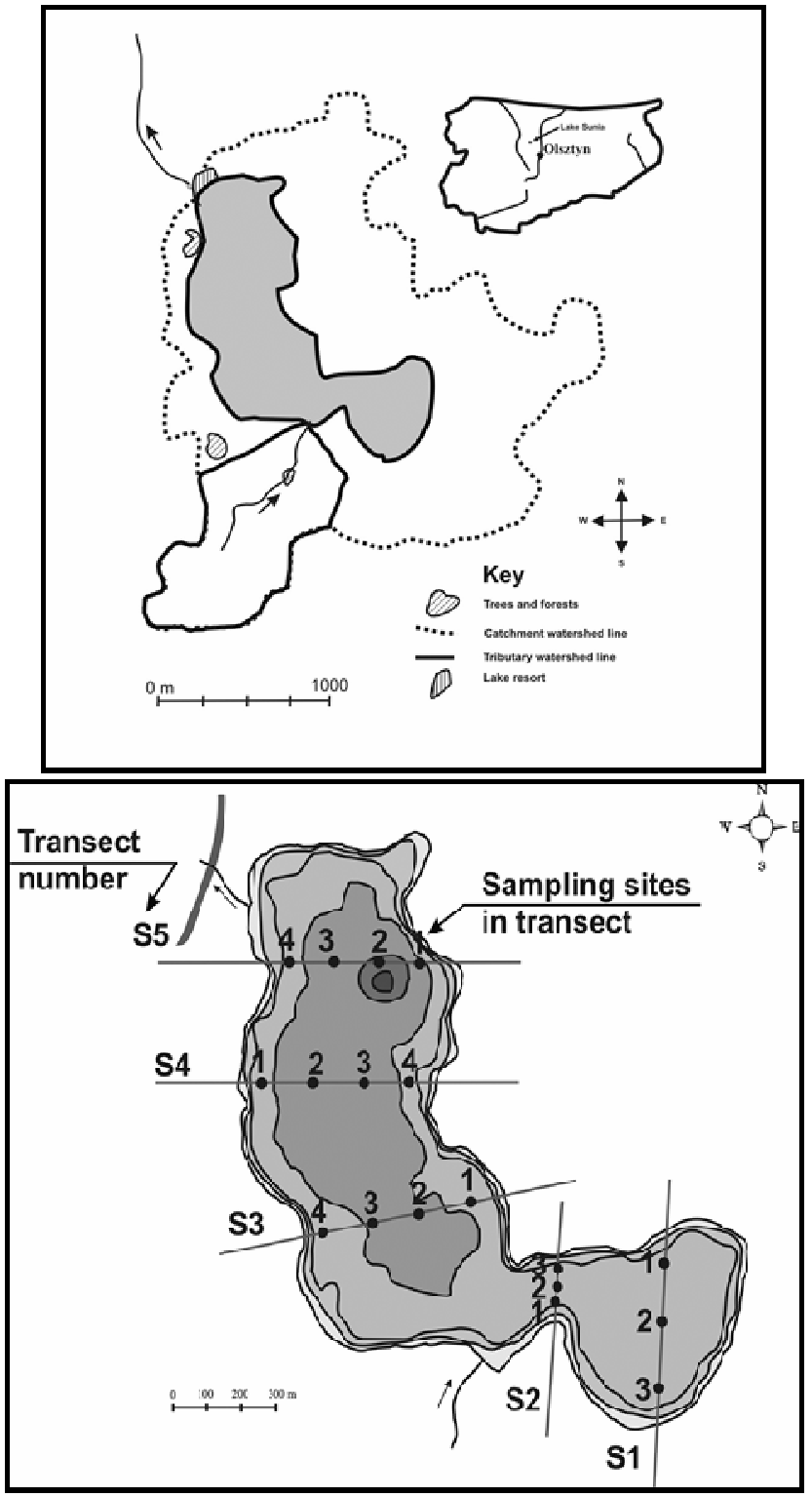

Fig. 1. Location of a) Lake Sunia and b) sampling sites in Lake Sunia

Samples of lake sediments for physical and chemical analyses were collected with an Ekman bottom grab (for collecting samples with a surface area of $250 \mathrm{~cm}^{2}$ ). The samples were obtained from five transverse transects with 3-4 sampling sites each (Fig. 1b). The sediments were analyzed to determine their allochthonous or autochthonous origin. The physical parameters of collected material were determined directly after sampling by the Troels-Smith method. 
During laboratory analyses, the following physicochemical parameters of fresh samples were investigated:

- $\quad$ Residue after evaporation - gravimetric analyses at $105^{\circ} \mathrm{C}\left(\mathrm{g} \cdot \mathrm{kg}^{-1} \mathrm{~d} . \mathrm{m}\right.$. $)$

- Residue after ignition - an indicator of organic matter content, calculated as the difference between residue after evaporation and residue after ignition $\left(\mathrm{g} \cdot \mathrm{kg}^{-1} \mathrm{~d}\right.$.m.)

Heavy metal concentrations in sediments were determined by atomic absorption spectroscopy (AAS) using the Varian Spectra AA100 spectrometer.

In order to identify the primary environmental factors affecting variability of metals in the tested sediment was performed multivariate statistical analyses involving a linear indirect method of Principal Components Analysis (PCA). The data was transformed to $\operatorname{logarithms} \log (n+1)$ to satisfy conditions of normality. The CANOCO 4.5 software was used to analysis of data [9].

\section{Results and discussion}

In terminal lakes, sediments are formed mainly by wave motion and seasonal vertical circulation of water. In flow-through lakes, the distribution of deposits is determined mainly by the river flowing through the water body. Upon reaching the lake, the river's flow rate decreases, and matter (sand grains, clayey formations and coarse detritus) suspended by the turbulent motion of the river water becomes settled. The properties of bottom sediments also depend on the distribution of lakes in the bowl. This is caused to the spatial variation of various sizes of particles sedimentation, runoff of bottom deposits along the lake basin slopes and diversity of organic material creating deposits of profundal and litoral [1, 10]. Gravitational deposition of matter is observed in glacial lakes. The highest rate of deposition is observed at the deepest point of the water body where the thickest sediments are generally accumulated [11].

Table 1

Dry matter content, density and $\mathrm{pH}$ of deposits in different zones of Lake Sunia

\begin{tabular}{|c|c|c|c|c|c|}
\hline \multirow{2}{*}{ Parameter } & \multicolumn{5}{|c|}{ Lake zone } \\
\cline { 2 - 5 } & Bay & $\begin{array}{c}\text { Shallow } \\
\text { zone }\end{array}$ & $\begin{array}{c}\text { Southern } \\
\text { section }\end{array}$ & $\begin{array}{c}\text { Central } \\
\text { section }\end{array}$ & $\begin{array}{c}\text { Northern } \\
\text { section }\end{array}$ \\
\hline Dry matter content $[\%]$ & 9.00 & 26.50 & 9.10 & 12.20 & 9.40 \\
\hline Density $\left[\mathrm{g} / \mathrm{cm}^{3}\right]$ & 1.08 & 1.66 & 1.15 & 1.01 & 1.07 \\
\hline $\mathrm{pH}$ & 7.41 & 7.40 & 7.41 & 7.43 & 7.42 \\
\hline
\end{tabular}

Important feature of the deposits from the viewpoint of physical and chemical conditions prevailing at the bottom of the quality of the organic substance [2]. Bottom deposits in Lake Sunia were entirely homogenous, and were characterized by significant morphological variation and average blackness at the level of Nig. 2. They contained highly decomposed plant matter (Humo at level 3-4, decomposition degree H7-H10 on the von Post scale). The sampled material varied significantly in terms of its water content (Sicc. level 2-3). The highest water content of $26.5 \%$ was noted in samples from the shallow zone of the lake, and the lowest water content of $9.0 \%$ was reported in samples from the lake bay (Table 1). The average dry matter content of the analyzed samples was $12.7 \pm 11.5 \%$ with a concentration median of $9.4 \%$. Bottom deposits varied considerably in their dry matter content. The analyzed material was characterized by relatively uniform density of 
$1.13 \pm 0.14 \mathrm{~g} \cdot \mathrm{cm}^{-3}$ on average (Table 2). The density median was $2.2 \mathrm{~g} \cdot \mathrm{cm}^{-3}$, and the coefficient of variation was determined at $12.4 \%$. The highest deposit density was reported in the shallow zone $\left(1.66 \mathrm{~g} \cdot \mathrm{cm}^{-3}\right)$, and the lowest - in the central part of the main water body $\left(1.01 \mathrm{~g} \cdot \mathrm{cm}^{-3}\right)($ Table 1$)$. The analyzed sediments were somewhat alkaline, and their $\mathrm{pH}$ in all sections of the lake was similar in the range of 7.40 to 7.43 .

Table 2

Density, dry matter content and $\mathrm{pH}$ of bottom deposits in Lake Sunia

\begin{tabular}{|c|c|c|c|}
\hline Parameter & Density $\left[\mathrm{g} / \mathrm{cm}^{3}\right]$ & Dry matter [\%] & pH \\
\hline Min & 1.01 & 7.40 & 7.40 \\
\hline Max & 1.66 & 57.00 & 7.43 \\
\hline Average & 1.13 & 12.70 & - \\
\hline Median & 2.20 & 9.40 & 7.41 \\
\hline SD & 0.14 & 11.50 & - \\
\hline $\begin{array}{l}\text { Coefficient of } \\
\text { variation }\end{array}$ & 12.40 & 90.00 & - \\
\hline
\end{tabular}

Deposited organic matter comprises fragments of dead organisms and organic suspensions, and it is formed through the precipitation and coagulation of dissolved organic substances. Its content in the surface layer of bottom deposits is determined by the amount of material produced in the trophogenic zone, the quantity of allochthonous matter and sedimentation rate [12]. The average organic matter content of Lake Sunia was $24.8 \pm 4.9 \%$ d.m. with a concentration median of $25.9 \%$ d.m. The above values are characteristic of glacial lakes whose organic matter content ranges from 10 to $70 \%$ d.m. (Table 3).

$\mathrm{Pb}, \mathrm{Zn}$ and $\mathrm{Cr}$ concentrations in the bottom deposits of Lake Sunia

\begin{tabular}{|c|c|c|c|c|}
\hline & $\begin{array}{c}\text { Pb } \\
{[\mathbf{m g} / \mathbf{k g ~ d . m .}]}\end{array}$ & $\begin{array}{c}\mathbf{Z n} \\
{[\mathbf{m g} / \mathbf{k g ~ d . m .}]}\end{array}$ & $\begin{array}{c}\mathbf{C r} \\
{[\mathbf{m g} / \mathbf{k g ~ d . m . ]}}\end{array}$ & $\begin{array}{c}\text { Organic } \\
\text { matter [\%] }\end{array}$ \\
\hline Min & 10.5 & 21.2 & 2.8 & 12.5 \\
\hline Max & 42.0 & 79.9 & 21.5 & 30.3 \\
\hline Average & 36.7 & 72.3 & 16.2 & 24.8 \\
\hline Median & 39.3 & 80.0 & 11.1 & 25.9 \\
\hline SD & 11.1 & 20.3 & 18.5 & 4.9 \\
\hline $\begin{array}{c}\text { Coefficient of } \\
\text { variation }\end{array}$ & 30 & 28 & 114 & 20 \\
\hline
\end{tabular}

The lowest organic matter levels (12.5\%) were reported in samples collected in the eastern part of the lake and in the shallow zone separating the lake from the bay.

Organic matter produced through precipitation and coagulation of dissolved organic substances has capillary structure. Its specific weight is similar to that of water [4, 13], which facilitates lifting and transport of particles. The above explains the low content of organic matter in samples collected from the shallow zone where deposits are depleted by wave motion which removes lighter particles. Shallow zones are more abundant in oxygen which promotes the mineralization of organic matter. High concentrations of organic matter in Lake Sunia could be attributed to high levels of primary production and the inflow of biogenic substances from an intensively farmed catchment area. 
Heavy metals present in lake deposits may become accumulated in the food chain to a level which is toxic for aquatic organisms, in particular predators, and which could also pose a health risk for humans. Deposits containing high concentrations of harmful substances are potential sources of environmental pollution. Heavy metals can be divided into two groups. The first includes elements that are required for essential bodily functions, such as zinc and copper, whereas the second group comprises metals that exert toxic effects on metabolic processes $(\mathrm{Cd}, \mathrm{Pb}, \mathrm{Cr}$ and $\mathrm{Co})$. Knowledge of content of heavy metals in water and sediments can be used for more detailed chemical characteristics of the aquatic environment and geochemical situation prevailing in the catchment, including the spread of contamination and to identify their sources [14].

The lead content of the rocks was depends from the type and amounts to 25-40 ppm [15]. During weathering processes lead runs slowly while quickly followed by the binding of minerals and organics ingredients, which often can lead to a secondary concentration [3].

The studied deposits were characterized by average lead content of $36.7 \pm 11.1 \mathrm{mg}$ $\mathrm{Pb} / \mathrm{kg}$ d.m. with a concentration median of $39.3 \mathrm{mg} \mathrm{Pb} \cdot \mathrm{kg}^{-1}$ d.m. and a coefficient of variation of $30 \%$. The highest lead concentrations were noted in deposits sampled from the eastern part of the lake $\left(47.5 \mathrm{mg} \mathrm{Pb} \cdot \mathrm{kg}^{-1} \mathrm{~d} . \mathrm{m}\right.$.) and from the southern section of the water body (Fig. 2). The geochemical background for lead in lakes of NE Poland is $11 \mathrm{mg} \mathrm{Pb} \cdot \mathrm{kg}^{-1}$ d.m., and lead concentrations in unpolluted sediments generally do not exceed $20 \mathrm{mg} \mathrm{Pb} \cdot \mathrm{kg}^{-1}$ d.m. [8]. Geochemical background is called "natural" substances in environmental samples, taking into account the spatial and time factors. There are determined of direct methods to the samples with minimal anthropogenic influence, or indirectly by statistical methods [16].

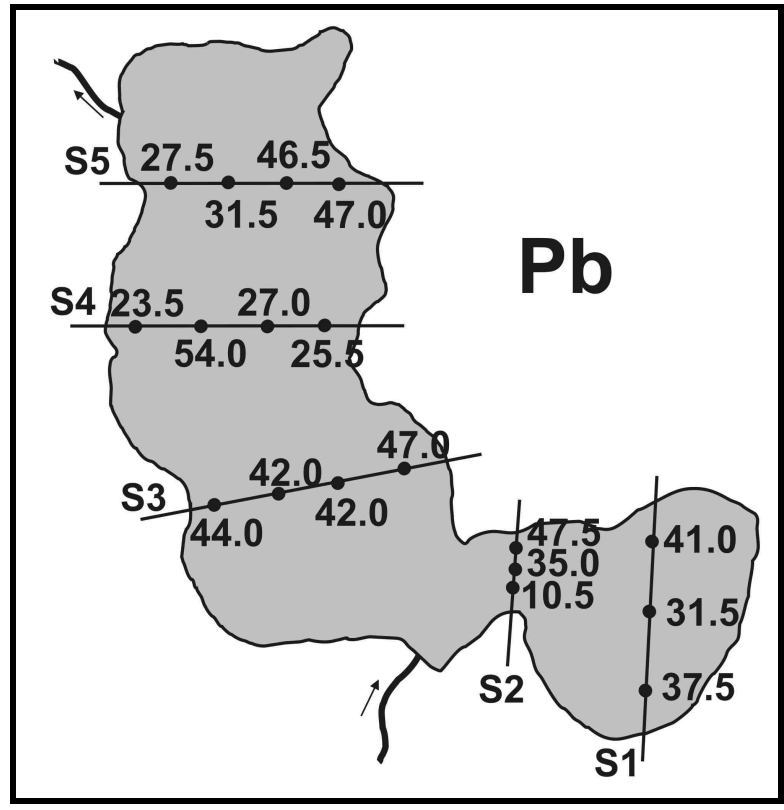

Fig. 2. Spatial distribution of $\mathrm{Pb}$ in the bottom deposits of Lake Sunia 
High lead levels in the sediments of Lake Sunia could be attributed to agricultural production in the catchment and the resulting application of mineral fertilizers and pesticides. The use of fuel to power farm equipment and atmospheric deposition which accounts for up to $77 \%$ of lead supply [17] could also contribute to high levels of the analyzed element in the sediments of Lake Sunia.

Zinc is an element that occurs widely in the earth's crust - usually in quantities of 10-125 ppm. [15]. During weathering processes all zinc compounds are readily soluble ions released from the mineral or combination of organic and mineral with a high mobility. Zinc solubility decreases in proportion to an increase in reaction [18]. The average zinc concentrations in the analyzed deposits were determined at $72.3 \pm 20.3 \mathrm{mg} \mathrm{Zn} \cdot \mathrm{kg}^{-1} \mathrm{~d} . \mathrm{m}$. with a coefficient of variation of $28 \%$ (Fig. 3). The geochemical background for zinc does not exceed $100 \mathrm{mg} \mathrm{Zn} \cdot \mathrm{kg}^{-1}$ d.m. [8].

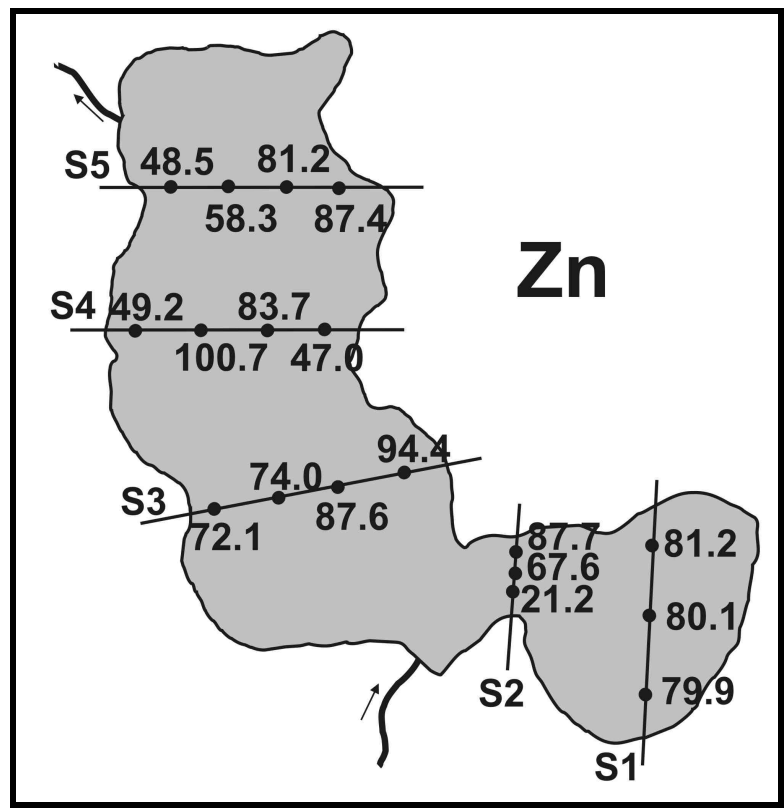

Fig. 3. Spatial distribution of $\mathrm{Zn}$ in the bottom deposits of Lake Sunia

Average $\mathrm{Zn}$ values were at the level of the geochemical background. The highest zinc levels were found in the central part of the lake $\left(100.6 \mathrm{mg} \mathrm{Zn} \cdot \mathrm{kg}^{-1} \mathrm{~d} . \mathrm{m}\right.$.), and the lowest in the area of the former resort and the lake outflow (48.5-49.2 $\mathrm{mg} \mathrm{Zn} \cdot \mathrm{kg}^{-1}$ d.m.) (Fig. 3). According to the sediment purity criteria proposed by Bojakowska and Sokolowska [19], the observed concentrations of $\mathrm{Zn}$ fall into purity class I.

Chromium compounds are supplied to surface waters with effluents from tanneries and metalworking plants, and their concentrations in the sediments of unpolluted lakes generally do not exceed $10 \mathrm{mg} \mathrm{Cr} \cdot \mathrm{kg}^{-1} \mathrm{~d} . \mathrm{m}$. The average chromium content of the studied lake was determined at $16.2 \pm 18.5 \mathrm{mg} \mathrm{Cr} / \mathrm{kg} \mathrm{d.m}$., and it ranged from $2.8 \mathrm{mg} \mathrm{Cr} \cdot \mathrm{kg}^{-1} \mathrm{~d} . \mathrm{m}$. in the shallow zone to $27.6 \mathrm{mg} \mathrm{Cr} \cdot \mathrm{kg}^{-1} \mathrm{~d} . \mathrm{m}$. in the bay (Fig. 4). 


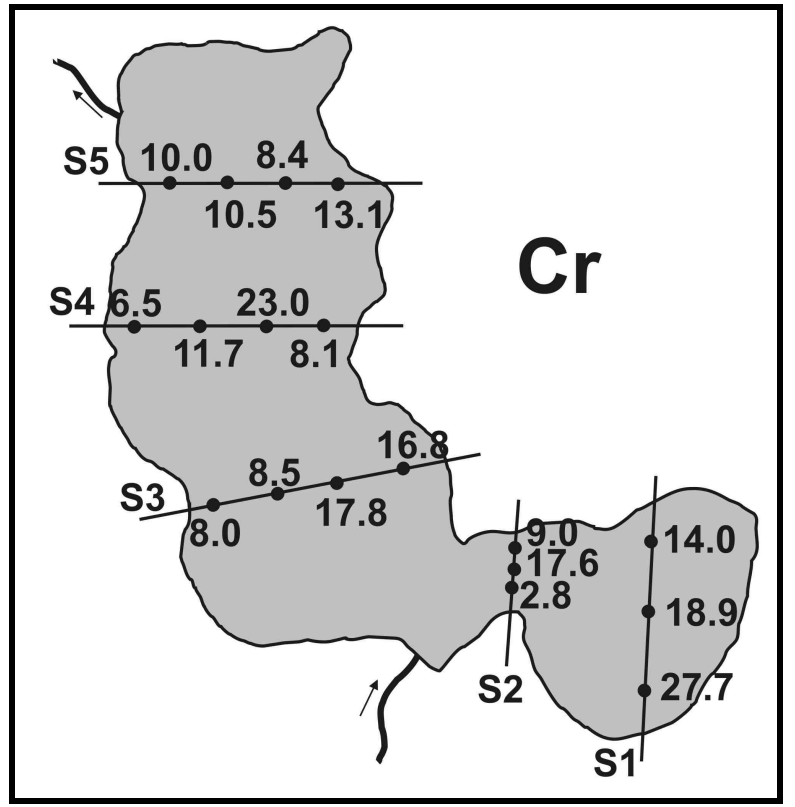

Fig. 4. Spatial distribution of $\mathrm{Cr}$ in the bottom deposits of Lake Sunia

The concentration median was $11.1 \mathrm{mg} \mathrm{Cr} \cdot \mathrm{kg}^{-1} \mathrm{~d} . \mathrm{m}$., and the coefficient of variation reached $114 \%$, which points to considerable variations in the spatial distribution of chromium in the deposits of Lake Sunia. The lowest levels of chromium were noted in the shallow zone. The above could be attributed to the release of chromium from bottom deposits due to water turbulence caused by wind.

Lead, zinc and chromium concentrations were lower in the littoral zone than in the profundal zone, which could be attributed to bioaccumulation. Sediments in deeper parts of the lake are characterized by a high content of organic matter and fine mineral fractions which bind metals $[11,20]$. In Lake Sunia, the lowest levels of trace elements were observed in the shallow zone separating the main body of the lake from the bay, whereas the highest concentrations were reported in the western part of the water body. The average concentrations of trace elements in the analyzed water body were arranged in the following series: $\mathrm{Cr}<\mathrm{Pb}<\mathrm{Zn}$, and their ratios were determined at $8.1<22.9<45.2$.

Lake deposits constitute "natural archives" which support observations of environmental changes on the local and regional scale. They are a source of valuable information about the underlying causes of those changes [14]. Metals and other substances can be immobilized in sediments for decades or even centuries [4].

The canonical axis (PCA 1) explained $81.4 \%$ of variation in tested metals. The second principal components (PCA 2) explained only $17.4 \%$ of variation (Fig. 5). Parameter such as lead and zinc were highly positive correlated with depth of lake (correlation coefficients were 0.188 and 0.342 , respectively). Bottom sediment situated up to 3 meters depth were characterized by higher accumulation of tested metals (about 22\% higher than average values for the littoral zone). In turn, the chromium content was highly negative correlated with location of sediment in water body. Bottom sediment located on bay zone were 
characterized by higher accumulation of $\mathrm{Cr}$ (about $21 \%$ higher than sediment location in main water body). The chromium was not correlated with depth of lake. The results show that inflow of Lake Sunia is not responsible for the accumulation of chromium in bottom sediment.

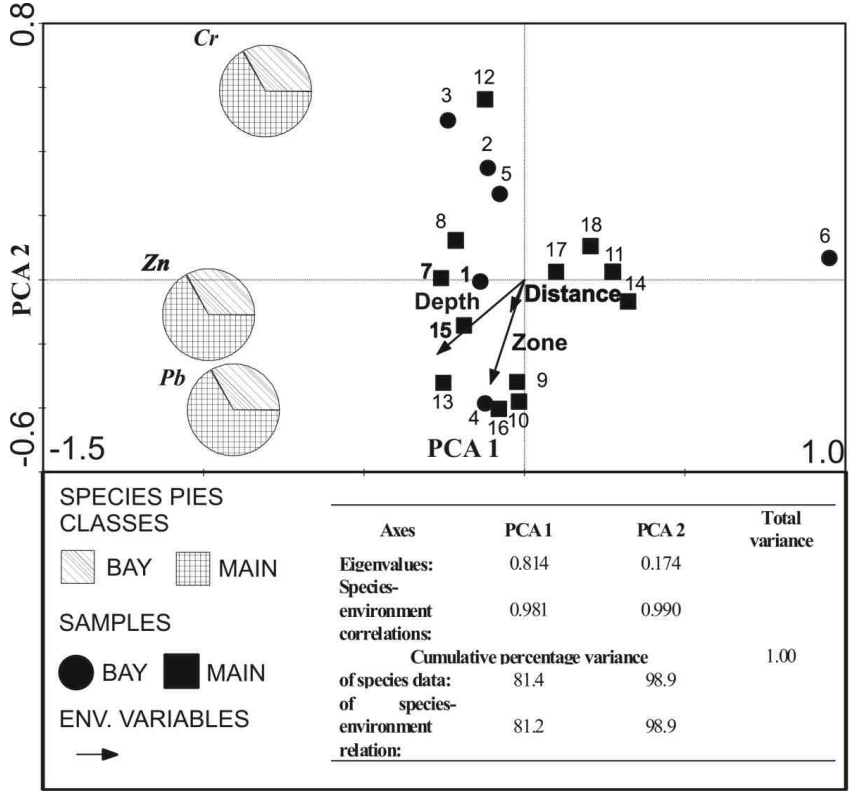

Fig. 5. The results of PCA analysis (analysis of impact of environmental variable on the tested metals)

The contaminated sediments are usually elevated levels of metals which are currently or have recently widely used in the farming and the running to environment during of mineral processing [1].

An analysis of lead, zinc and chromium loads in bottom deposits revealed the highest accumulation levels of zinc ( $2232 \mathrm{~kg}$ per lake). The zinc load per hectare of the studied lake was determined at $20 \mathrm{~kg}$, and the load in the catchment area - at $4.9 \mathrm{~kg}$. Zinc levels were nearly $50 \%$ higher than lead concentrations in the analyzed lake. In the studied sediments, lead accumulation reached $1137.7 \mathrm{~kg}$ and chromium accumulation - $399.9 \mathrm{~kg}$. The above implies that outflows from intensively farmed areas are the key contributors to heavy metal concentrations in Lake Sunia.

\section{Conclusions}

1. Bottom deposits in Lake Sunia were characterized by significant morphological variation and water content Sicc. at the level of 2-3. The average organic matter concentrations were determined at $24.8 \%$ d.m. The lowest levels of organic matter $(12.5 \%)$ were reported in samples collected on the eastern side of the transect in the main lake body, and the highest levels were noted in the bay (30.3\%). 
2. The spatial distribution of lead, zinc and chromium was varied. Higher heavy metal concentrations were observed in the profundal zone, in sediments sampled in the eastern part of the lake and at deeper locations, whereas lower metal levels were reported in the littoral zone.

3. The average concentrations of trace elements in the analyzed water body were arranged in the following series: $\mathrm{Cr}<\mathrm{Pb}<\mathrm{Zn}$, and their ratios were determined at $8.1<22.9<45.2$. Zinc was accumulated in the highest amount (2232.0 kg per lake), and its total load exceeded lead accumulations by $50 \%$ and chromium accumulations by $80 \%$.

\section{References}

[1] Yuan X, Zhang L, Li J, Wang Ch, Ji J. Catena. 2014;119:52-60. DOI: 10.1016.j.catena.2014.03.008.

[2] Macintosh KA, Griffiths DC. Environ Earth Sci. 2013;70(7):3023-3030. DOI: 10.1007/s12665-013-2363-6.

[3] Lu Ch, Cheng J. Proc Eng. 2011;18:318-323. DOI: 10.1016/i.proeng.2011.11.050.

[4] Skwierawski A, Sidoruk M. Ecol Chem Eng S. 2014;21(1):79-88. DOI: 10.2478/eces-2014-0007.

[5] Szymczyk S, Grabińska B, Koc-Jurczyk J. Concentrations of $\mathrm{Zn}, \mathrm{Pb}, \mathrm{Cd}$ and $\mathrm{Ni}$ in the waters of the Narew River and some of its tributaries. J Elem. 2007;12(3):199-205.

[6] Selvam AP, Priya SL, Banerjee K, Hariharan G, Purvaja R, Ramesh R. Environ Monit Asses. 2011;184(10):5899-5915. DOI: 10.1007/s10661-011-2389-8.

[7] Nedjai R, Bguyen-Trung C, Messaoud-Nacer N. J Advan Chem Eng. 2011;1:1-10. DOI: 10.1303/jace/A110303.

[8] Bojakowska I, Gliwicz T. Wyniki geochemicznych badań osadów wodnych Polski w latach 2000-2002. Biblioteka Monitoringu Środowiska. 2003;46-81.

[9] ter Braak CJF, Šmilauer P. CANOCO Reference Manual and CanoDraw for Windows User's Guide: Software for Canonical Community Ordination (version 4.5). USA: Microcomputer Power. Ithaca NY; 2005.

[10] Song Y, Ji J, Yang Z, Mao C, Frost RL, Ayoko GA. Catena. 2011;85(1):73-81. DOI: 10.1016/j.catena.2010.12.009

[11] Hou D, He J, Lu C, Ren L, Fan Q, Wang J, et al. Ecotox Environ Safety. 2013;93:135-144. DOI: 10.1016/j.ecoenv.2013.03.012.

[12] Lozba-Ştirbyleac RS, Giurma-Handley CR, Giurma I. Water quality characterization of the Prut River. EEMJ. 2011;10(3):411-419.

[13] Sidoruk M, Rochwerger A, Skorbiłowicz E, Skorbiłowicz M. Effect of land use on lead and zinc accumulation in bottom sediments on the basis of Ardung and Bukwałd lakes. Ecol Chem Eng A. 2011;18(12):1633-1640. http://tchie.uni.opole.pl/ece_a/A_18_12/ECE_A_18\%2812\%29.pdf.

[14] Glińska-Lewczuk K, Skwierawski A, Kobus S, Sidoruk M, Krzyzaniak M. Spatial distribution of heavy metals $(\mathrm{Cr}, \mathrm{Cu}, \mathrm{Zn}$ and $\mathrm{Pb})$ in bottom sediments of a oxbow Lakes in Northern Poland differed by hydrological connectivity. Fres Environ Bull. 2009;18(7):1138-1148.

[15] Wojtkowska M. Bull B Environ Contam Tox. 2013;90:65-169. DOI: 10.1007/s00128-012-0881-7.

[16] Dung T, Cappuyns V, Swennen R, Phung NK. Rev Environ Sci Biotechnol. 2013;2:335-353. DOI: 10.1007/s11157-013-9315-1.

[17] Nicholson FA, Smith SR, Alloway BJ, Carlton-Smith C, Chambers BJ. An inventory of heavy metals inputs to agricultural soils in England and Wales. Sci Total Environ. 2003;311:205-219.

[18] Glińska-Lewczuk K, Bieniek A, Sowiński P, Obolewski K, Burnadt P, Timofte C. J Elemen. 2014;2:361-376. DOI: 10.5601/jelem.2014.19.1.618.

[19] Bojakowska I., Sokołowska G. Geochemiczne klasy czystości osadów wodnych. Przegląd Geolog. 1998;46:49-54.

[20] Szalińska E, Grgciak-Mannion A, Haffner D, Droullard KG. Chemosphere. 2013;93:1773-1781. DOI: 10.1016/j.chemosphere.2013.06.009. 


\title{
ROZKŁAD PRZESTRZENNY OŁOWIU, CYNKU I CHROMU W OSADACH DENNYCH JEZIORA SUNIA
}

\author{
Katedra Gospodarki Wodnej, Klimatologii i Kształtowania Środowiska \\ Uniwersytet Warmińsko-Mazurski w Olsztynie
}

\begin{abstract}
Abstrakt: Osady denne są miejscem akumulacji różnych pierwiastków w ilościach znacznie przekraczających zawartość w wodzie jeziornej. W pewnych warunkach mogą wtórnie zanieczyszczać toń wodną i stanowić zagrożenie dla bytujących w nich organizmów. Przeprowadzone badania miały na celu oszacowanie stopnia przestrzennego zanieczyszczenia $\mathrm{Pb}, \mathrm{Zn}$ oraz $\mathrm{Cr}$ osadów dennych jeziora Sunia. Obiekt badawczy położony jest na obszarze Pojezierza Olsztyńskiego (zachodnia część Pojezierza Mazurskiego), około $30 \mathrm{~km}$ na północ od Olsztyna w gminie Świątki. Powierzchnia jeziora wynosi 111,6 ha, a maksymalna głębokość 8,8 m. Dopływ do jeziora stanowi rzeka po stronie południowo-zachodniej, zaś odpływ znajduje się w północno-zachodniej części akwenu. Akwen posiada zatokę oddzieloną od głównego akwenu wypłyceniem. Zlewnię jeziora stanowią głównie użytki rolne. Całkowity obszar zasilania jeziora wynosi 450 ha, z czego powierzchnia zlewni dopływu wynosi 70 ha. Obszar zlewni w większości zajmują użytki rolne (91\%), a w szczególności grunty orne, pozostałą część zlewni (5\%) stanowią nieużytki oraz zadrzewienia (4\%). Na obszarze zasilania jeziora dominują gleby gliniasto-piaszczyste przechodzące w piaski gliniaste mocne i gliny słabo piaszczyste. Pod względem uziarnienia są to gleby zwięzłe, które trudno przepuszczają wodę i składniki pokarmowe. Biorąc pod uwagę klasyfikację bonitacyjną gleb, w przeważającej ilości są to gleby zaliczane do klasy IVa, IIIa i IIIb. Średnia zawartość materii organicznej w osadach jeziora wynosiła $24 \%$. Znaczna zawartość materii organicznej jest skutkiem intensywnego dopływu substancji biogennych z jego zlewni, w której prowadzona jest intensywna gospodarka rolna. Wartości średniej koncentracji pierwiastków śladowych w zbiorniku układają się w następujące szeregi: $\mathrm{Cr}<\mathrm{Pb}<\mathrm{Zn}$, a ich wzajemne proporcje kształtują się na następującym poziomie: $8,1<22,9<45,2$. Najwyższe koncentracje metali ciężkich obserwuje się w litoralu.
\end{abstract}

Słowa kluczowe: antropopresja, osady denne, metale ciężkie 